\title{
The effect of testosterone, dihydrotestosterone and oestradiol on the re-initiation of spermatogenesis in the adult photoinhibited Djungarian hamster
}

\author{
Sarah J Meachem ${ }^{1,2}$, Stefan Schlatt ${ }^{2,3}$, Saleela M Ruwanpura ${ }^{1}$ and Peter G Stanton ${ }^{\mathbf{1}}$ \\ ${ }^{1}$ Prince Henry's Institute of Medical Research, Level 4, 43-51 Kanooka Grove, Clayton, Victoria, 3168 Australia \\ ${ }^{2}$ Institute of Reproductive Medicine, University of Münster, Münster, Germany \\ ${ }^{3}$ University of Pittsburgh School of Medicine, Pittsburgh, Pennsylvania, USA \\ (Requests for offprints should be addressed to S J Meachem; Email: sarah.meachem@princehenrys.org)
}

\begin{abstract}
The roles of testosterone ( $T$ ) and its metabolites on hamster spermatogenesis are poorly defined. This study assessed the effects of T, dihydrotestosterone (DHT) and oestradiol (E) on the re-initiation of spermatogenesis in the adult Djungarian hamster. Hamsters raised under long photoperiods (LD, $16 \mathrm{~h}$ light: $8 \mathrm{~h}$ darkness) were exposed to short photoperiods (SD, $8 \mathrm{~h}$ light:16 h darkness) for 11 weeks to suppress gonadotrophins. Groups of eight animals then received T, DHT and E for 5 weeks. Cell numbers were determined using the optical disector (sic). The number of Sertoli cells was suppressed in SD controls to $48 \%(P<0.001)$ of LD control and restored either fully or partially by exogenous DHT and $\mathrm{E}$ (2.6- and $1 \cdot 8$-fold above SD levels) respectively, corresponding with a twofold elevation of serum FSH. The number of germ cells in SD animals was reduced (all $P<0 \cdot 001$ ) to levels
\end{abstract}

reported. The number of type A spermatogonia increased in line with the rise in Sertoli cell number, by $2 \cdot 6$-fold $(P<0 \cdot 01)$ and 1.8-fold (NS) above SD controls after DHT and E treatments respectively. DHT increased the number of type B spermatogonia/preleptotene spermatocytes, leptotene/ zygotene and pachytene spermatocytes by $3 \cdot 5-, 5 \cdot 7-$ and 21 -fold above SD (all $P<0 \cdot 01$ ) respectively, compared with a 2.2-fold $(P<0 \cdot 01), 2 \cdot 4$-fold (not significant, NS) and 6-fold (NS) in E-treated animals respectively. Exogenous T had little effect on cell numbers or serum FSH compared with SD controls. Spermatids were rarely observed after steroid treatment. We believe this study suggests that steroids can regulate the re-initiation of early spermatogenic cells via a mechanism which includes FSH.

Journal of Endocrinology (2007) 192, 553-561

\section{Introduction}

Sperm production (Lerchl et al. 1993) and fertility (Niklowitz et al. 1997) in the photoinhibited Djungarian hamster have been shown to be highly dependent on follicle stimulating hormone (FSH) with testosterone (T) only necessary for mounting behaviour (Lerchl et al. 1993). Consistent with this, spermatogenesis spontaneously resumes after lengthy (15 weeks) periods of short day (SD) conditions with this resumption being associated with a prompt rise in serum FSH but not $\mathrm{T}$ (Milette $e t$ al. 1988, Schlatt et al. 1995). The Djungarian hamster is considered unusual compared to our understanding of the hormonal regulation of spermatogenesis in other rodent models. Extensive research in mice and rats show that although FSH plays a key role in early germ cell development, it is incapable of supporting meiosis and spermatid maturation and completion of this process depends on $\mathrm{T}$ (McLachlan et al. 2002). The Djungarian hamster is a seasonal breeder and photoinhibition suppresses pituitary luteinizing hormone (LH; and as a result testicular T to $5 \%$ of normal levels) and FSH, and as a consequence, spermatogenesis is disrupted primarily during spermatogonial development (Bergmann 1987, Lerchl et al. 1993, Schlatt et al. 1995). This profound spermatogenic suppression is not observed in gonadotrophin-deplete mice and rats, making the Djungarian hamster an ideal model to study hormonal control of spermatogonia. When testicular T levels were partially restored to $30 \%$ of long day (LD) control in the Djungarian hamster by exogenous LH treatment (Niklowitz et al. 1989), which in the adult rat is sufficient to fully maintain and support spermatogenesis (McLachlan et al. 2002), little to no changes were observed in testis weight, seminiferous tubule lumen development, tubule diameter and spermatogenesis (Niklowitz et al. 1989). A mild increase (twofold above photoinhibited or SD control) in primary spermatocytes number was observed; however, the accuracy of this result remains uncertain given that the method of stereological quantification was not described (Niklowitz et al. 1989). Another study reported that $\mathrm{T}$ treatment (Silastic implants of between 0.5 and $1.5 \mathrm{~cm}$ for 8 weeks) given to photoinhibited hamsters did not affect testis weight, germ cell number (per testis 
basis) as assessed by flow cytometry, sperm number, fertility or litter size (Lerchl et al. 1993). However, it should be noted that this treatment also failed to show an increase in testicular $\mathrm{T}$ levels above that of photoinhibited controls (Lerchl et al. 1993). Hence, there is little data available to support an action of $\mathrm{T}$ in the re-initiation of spermatogenesis in the SD hamster.

Testosterone can be irreversibly metabolised in the testicular and peripheral tissues by either $5 \alpha$-reduction to dihydrotestosterone (DHT) or aromatisation to $\mathrm{E}$ (Wilson 1975). Although $\mathrm{T}$ is the predominant androgen in the normal testis, it is recognised that DHT is the more potent androgen (Grino et al. 1990, Deslypere et al. 1992, Chen et al. 1994, Zhou et al. 1995, O'Donnell et al. 1996) and that in the setting of low testicular T, DHT plays an important role in supporting spermatogenesis in the adult rat (O'Donnell et al. 1996, 1999). Evidence supporting a direct action of $\mathrm{E}$ on spermatogenesis is lacking, although oestrogens are important for fluid absorption in the epididymis (for review, see Hess et al. 1997, O'Donnell et al. 2001, Oliveira et al. 2001, 2002). Direct effects of E have been reported in the aromatase-deficient (Robertson et al. 1999) and the congenital gonadotrophin-releasing hormonedeficient (hpg) (Ebling et al. 2000) mouse. In this latter study, exogenous $\mathrm{E}$ was shown to induce spermatogenesis although these effects may have been due to stimulation of FSH production (Ebling et al. 2000). In the adult Djungarian hamster testis, a novel role for E, independent of apparent FSH action, has been reported in the re-initiation of spermatogenesis following photoinhibition (Pak et al. 2002). Exogenous E has also been shown to induce germ cell apoptosis in the adult Syrian hamster, although serum T and FSH were also reduced in this model which confounds the interpretation of this data (Nonclercq et al. 1996).

The present study sought to determine the long-term (33 days) effect of T, DHT and E on the re-initiation of the spermatogenic process in the photoinhibited Djungarian hamster. To determine changes in cell populations, the optical disector (sic) stereological technique was used to quantify spermatogonial, spermatocyte, spermatid and Sertoli cell numbers following hormonal manipulation. Serum and testicular steroid levels were monitored in all groups. This study found that both androgen and oestrogen can upregulate Sertoli and early germ cell populations, but that neither steroid was effective in supporting spermiogenic cells. The data also suggest that an additional factor, presumably FSH, is required for full spermatogenesis in this model (Lerchl et al. 1993, Meachem et al. 2005).

\section{Materials and Methods}

\section{Animals}

Forty adult Djungarian hamsters (also called Siberian hamsters, Phodopus sungorus) were bred, raised and housed for up to 180 days under artificial LD or SD photoperiods at a constant temperature $\left(22^{\circ} \mathrm{C}\right)$ with free access to pelleted food and water in the colony of the Institute of Reproductive Medicine, University Münster, Germany (for details Lerchl 1995). All experiments were in accordance with local guidelines and with German law on the care and use of laboratory animals. All hamsters included in the experiments had large testes as determined by palpation at the onset of the experiment.

\section{Steroid implants}

Implants were made with either T (Sigma; T-1500), DHT (Sigma; A-8380, $5 \alpha$-androstan-17 $\beta$-ol-3-one) or E (Sigma; $\beta$-8875, $\beta$-oestradiol (1,3,5 (10)-estratriene-3,17 $\beta$-diol)) into $3 \mathrm{~cm}$ implants medical-grade polydimethylsiloxane Silastic tubing (Dow Corning Corp., Midland, MO, USA; inner diameter, $1.59 \mathrm{~mm}$; outer diameter, $3.18 \mathrm{~mm}$ ) plugged at each end with medical adhesive silicone type $\mathrm{A}$ as previously described (Robaire et al. 1979). In terms of E-filled Silastic implants, E was mixed 1:10 (10\%), by weight with cholesterol (Sigma Chemical Co., C-8667; cholesten-3$\beta$-ol, cholesterol was used as a packing agent only). All steroid doses were exactly as reported by Ebling et al. (2000) in the study of spermatogenic regulation in mice.

\section{Experimental design}

Suppression phase by photoinhibition Five groups of hamsters ( $n=8$ per group) were used. Thirty-two LD $(16 \mathrm{~h}$ light $/ 8 \mathrm{~h}$ darkness) hamsters were transferred into SD photoperiods ( $8 \mathrm{~h} \mathrm{light} / 16 \mathrm{~h}$ darkness) for 11 weeks to inhibit reproductive function. One group of hamsters $(n=8)$ remained under long photoperiods as reproductively active LD controls. The response to photoinhibition was assessed by palpation after which all hamsters with no palpable testes were included in the study. Hamsters were then allocated to one of the four groups, three groups of which received steroid treatment.

Recovery phase by hormone treatment Photoinhibited animals received either T, DHT or E-filled Silastic implants for 33 days (nearing to one full cycle of spermatogenesis, with one cycle of spermatogenesis being 35 days and 7.9 days for the cycle of the seminiferous epithelium (Van Haaster \& De Rooij 1993). Two groups of control animals were used, photoinhibited (SD) and photostimulated (LD), both of which received $3 \mathrm{~cm}$ filled cholesterol implants. All animals were killed by decapitation under anaesthesia after 33 days of steroid treatment. Hamsters were aged between 150 and 180 days old at the time of death.

\section{Tissue collection}

Trunk blood was collected and allowed to clot overnight at $4{ }^{\circ} \mathrm{C}$ prior to serum collection for hormone assays. Testes, prostates, seminal vesicles and gonadal fat pads were then excised and weighed. The left testis was immersion-fixed in Bouin's solution for $<5 \mathrm{~h}$. For testes $>50 \mathrm{mg}$, tissue was sliced into $2-3 \mathrm{~mm}$ thick slabs orthogonal to the long axis of 
the testis. For LD hamster testes, two of the four slabs were selected using a systematic random sampling scheme, for testes between 50 and $150 \mathrm{mg}$, one of the two slabs was selected, while $<50 \mathrm{mg}$ testes were processed whole and embedded into hydroxyethylmethacrylate resin (Technovit 7100: Kulzer and Co. GmBH, Friedrichsdorf, Germany) according to the manufacturer's instructions. Thick resin sections $(25 \mu \mathrm{m})$ were serially cut (Supercut Microtome, Reichert Jung 2050, Nussloch, Germany), stained with the Periodic acid - Schiff's reaction reagents and counterstained with Mayer's haematoxylin as previously described (Meachem et al. 1997) for the determination of cell number. All slides were masked prior to estimation of germ cell number.

\section{Cell number estimates using the optical disector method}

The optical disector method (Wreford 1995) was used to determine the total number of cells per testis as previously described (Meachem et al. 1996, 1997). Hamster germ cells were identified using the morphological criteria of Van Haaster \& de Rooij (1993) with similar criteria used for rats (Russell et al. 1990) as previously described (McLachlan et al. 1994). A total number of 80-300 nuclei of each cell type were counted per animal, except for pachytene spermatocytes and spermatids in SD hamster as few cells were observed. One unbiased counting frame in each field (area of each frame being $459 \mu^{2}$ ) was employed to count Sertoli cells and early germ cell types (spermatogonia through to zygotene spermatocytes) in SD hamsters, while one unbiased counting frame in each field $\left(2923 \mu \mathrm{m}^{2}\right)$ was used for LD hamsters. Pachytene spermatocytes were counted in one frame per field $\left(2088 \mu \mathrm{m}^{2}\right)$, while spermatids were counted using a set of two unbiased counting frames $\left(2 \times 459 \mu^{2}\right)$ per field. Cells were counted in a depth of $10 \mu \mathrm{m}$. The final screen magnification was $2708 \times$. As previously determined, no correction for shrinkage was required (McLachlan et al. 1995, Meachem et al. 1996).

The number of Sertoli and germ cells per testis was estimated for all groups. Germ cells were counted in the following categories: type A spermatogonia (across all stages)/intermediate spermatogonia (associated with stages I-IV); type B spermatogonia/preleptotene spermatocytes (associated with stages V-VIII), leptotene/zygotene spermatocytes (associated with stages IX-XII); pachytene spermatocytes (associated with stages I-XII); round (associated with stages I-VIII) and elongating and elongated spermatids (associated with stages I-XII).

\section{Serum testosterone assay}

Serum T levels were measured by RIA after ether extraction as described (Chandolia et al. 1991). Serum samples were assayed in duplicate across a single assay. Assay sensitivity for serum was $0.4 \mathrm{ng} / \mathrm{ml}$ and the within-assay coefficient of variation was $6 \%$.
Testicular steroid assays

Intratesticular T, DHT, $3 \alpha$-Adiol and $3 \beta$-Adiol were measured in testis homogenates (20-40 mg tissue/sample for SD animals, 140-240 mg/sample for LD animals), using HPLC and RIA, as described (O'Donnell et al. 1996, McLachlan et al. 2002). Steroid recoveries (\%) per sample were monitored using radiolabelled ${ }^{3} \mathrm{H}-\mathrm{T},{ }^{3} \mathrm{H}-\mathrm{DHT}$ (NEN Life Science Products, Boston, MA, USA), ${ }^{3} \mathrm{H}-3 \alpha$-Adiol and ${ }^{3} \mathrm{H}-3 \beta$-Adiol (O’Donnell et al. 1996, McLachlan et al. 2002) and were (mean \pm s.D., $n=39$ for all groups) T $60 \cdot 0 \pm 9 \cdot 8$, DHT $47 \cdot 7 \pm 4 \cdot 3,3 \alpha$-Adiol $56 \cdot 1 \pm 5 \cdot 0$ and $3 \beta$-Adiol $55 \cdot 0 \pm$ $5 \cdot 3$. All samples were assayed in 1-2 assays. Inter-assay and intra-assay variations were all $<14 \cdot 1$ and $8 \cdot 8 \%$ respectively, as reported (Matthiesson et al. 2005). The sensitivities of the combined extraction, HPLC and RIAs, were calculated from the average recoveries of tritiated steroid, the average tissue mass extracted for analysis and the sensitivity of each RIA. These values were $0 \cdot 15 \mathrm{ng} / \mathrm{g}$ testis for $\mathrm{T}, 0 \cdot 30 \mathrm{ng} / \mathrm{g}$ testis for DHT, $0.31 \mathrm{ng} / \mathrm{g}$ testis for $3 \alpha$-Adiol and $0.61 \mathrm{ng} / \mathrm{g}$ testis for $3 \beta$-Adiol.

\section{FSH assay}

Serum FSH was measured by a heterologous RIA (Amersham FSH-kit RPA 550) as described for rats (Bartlett et al. 1989) and hamsters (Schlatt et al. 1995). NIADDK FSH standards (rat FSH-RP-2), tracer (FSH-I-6) and antisera rFSH-11 were used. Quality controls were rat sera from normal (values ranged between 13 and $18 \mathrm{ng} / \mathrm{ml}$ ) and castrate $(50-80 \mathrm{ng} / \mathrm{ml}$ ) animals. The detection limit of the assay was $1 \cdot 2 \mathrm{ng} / \mathrm{ml}$ and the within-assay coefficient of variation was $9 \cdot 8 \%$.

\section{Statistical analysis}

Treatment groups were compared with SD controls using the Tukey's test or in the case of unequal variance, Dunn's method, for body and organ weights, serum FSH and cell populations using the program Sigmastat for Windows version 2.0 (Jandel Corporation, San Raphael, CA, USA). Data for steroid concentrations were analysed using GB Stat (Dynamic Systems Inc, Silver Spring, MD, USA) with post hoc analysis by the Student-Newman-Keuls test. The data are expressed as means \pm s.E.M., except for androgen concentrations (mean \pm s.D.), with $n=6-8$ animals/group.

\section{Results}

\section{Body weights}

Body weights were reduced $(P<0 \cdot 001)$ in SD control compared with LD controls (Fig. 1). Steroid administration did not affect body weight compared with their corresponding SD controls (Fig. 1). 
(g)

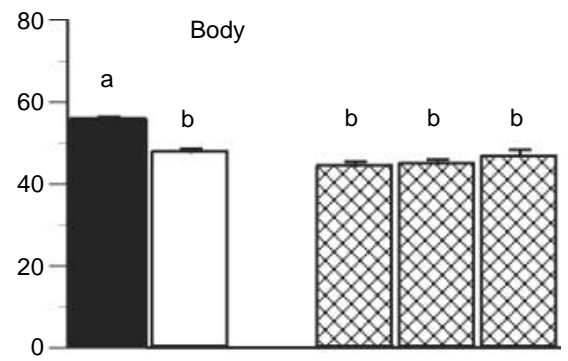

(mg)

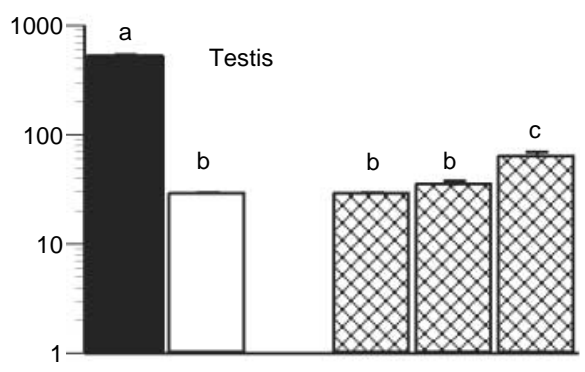

(mg)
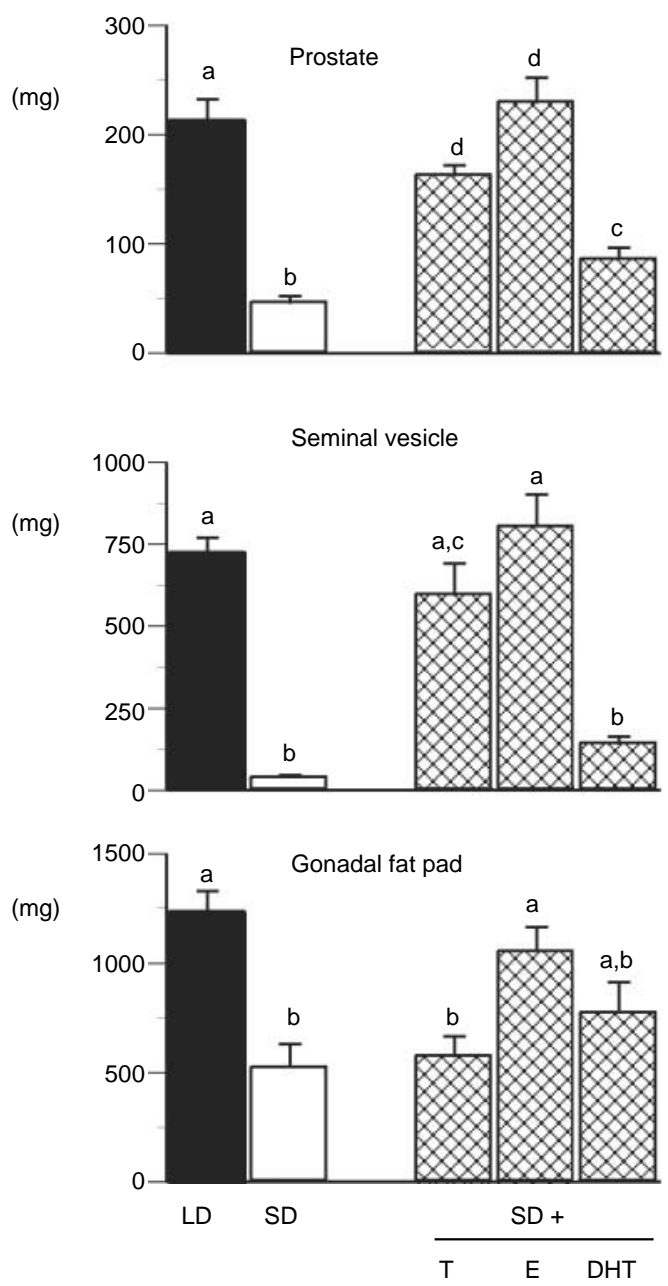

\section{Testicular weights}

Testicular weights (Fig. 1) from SD animals were reduced $(P<0 \cdot 001)$ to $6 \%$ of LD control values. In response to 33 days of $\mathrm{T}$ and $\mathrm{E}$ administration, testicular weights were not altered from SD control, being 6 and 7\% of LD control respectively. DHT administration increased testicular weights twofold above SD controls (12\% of LD controls, $P<0 \cdot 05$, Fig. 1$)$.

\section{Prostate weights}

Prostate weights for SD controls were reduced to $21 \%$ of LD controls $(P<0 \cdot 001$, Fig. 1$)$. Testosterone, DHT and E administration to SD animals increased prostate weights compared with SD controls to 76, 40 and 108\% of LD values respectively $(P<0 \cdot 01)$.

\section{Seminal vesicle weights}

Seminal vesicle weights for SD controls were reduced to $5 \%$ of LD control animals $(P<0 \cdot 001$, Fig. 1$)$. In response to T and E treatments, seminal vesicle weights were restored to normal weights (82 and 111\% respectively), while DHT administration gave a $3 \cdot 8$-fold increase in seminal vesicle weight compared with SD control (19.4\% of LD control); however, this did not achieve significance.

\section{Gonadal fat pad weights}

Gonadal fat pad weights for SD controls were reduced to $42 \%$ of LD control values $(P<0 \cdot 001$, Fig. 1$)$. In response to T and DHT administration, gonadal fat pad weights remained at SD control values, while $\mathrm{E}$ administration increased $(P<0 \cdot 01)$ gonadal fat pad weights above that of SD controls to $86 \%$ of LD control values.

\section{Hormone levels}

Serum FSH levels were reduced to the detection limit of the assay $(1.2 \mathrm{ng} / \mathrm{ml})$ in SD controls and were at least threefold less than LD controls $(P<0 \cdot 01$; Table 1$)$. Administration of $\mathrm{E}$ and DHT mildly increased serum FSH levels but this did not achieve significance, while the $\mathrm{T}$-treated group remained at SD control values.

Serum $\mathrm{T}$ levels in SD hamsters were not significantly reduced compared with LD controls, but remained near the detection limit of the assay (Table 1). Administration of

Figure 1 Body and organ weights in photo-stimulated (long day, LD) adult Djungarian hamsters that were exposed to short photoperiods (short day, SD) for 11 weeks. Hamsters were then given $3 \mathrm{~cm}$ Silastic implants filled with testosterone (T), oestradiol (E, $10 \%$ in cholesterol) or dihydrotestosterone (DHT) for 33 days. LD and SD controls received $3 \mathrm{~cm}$ cholesterol-filled Silastic implants. Data are means \pm s.E.M., $n=8$ hamsters/group. Letters denote significant differences between the treatment groups at $P<0 \cdot 05$ or less (see text for specifics). 
Table 1 Serum hormone concentrations in the photostimulated (long day, LD) adult Djungarian hamsters that were exposed to short photoperiods (short day, SD) for 11 weeks. Data are means \pm s.E.M., $n=8$ hamsters/group

\begin{tabular}{|c|c|}
\hline Serum FSH $(\mathrm{ng} / \mathrm{ml})$ & Serum $\mathbf{T}(\mathrm{ng} / \mathrm{ml})$ \\
\hline $3 \cdot 78 \pm 0 \cdot 38^{\mathrm{a}}$ & $1 \cdot 13 \pm 0 \cdot 12^{\mathrm{a}}$ \\
\hline $1 \cdot 23 \pm 0 \cdot 54^{b}$ & $0 \cdot 86 \pm 0 \cdot 12^{a}$ \\
\hline $1 \cdot 55 \pm 0 \cdot 44^{b}$ & $0 \cdot 66 \pm 0 \cdot 06^{a}$ \\
\hline $2 \cdot 68 \pm 0 \cdot 38^{a, b}$ & $1 \cdot 02 \pm 0 \cdot 17^{\mathrm{a}}$ \\
\hline $2 \cdot 71 \pm 0 \cdot 27^{\mathrm{a}, \mathrm{b}}$ & $1 \cdot 52 \pm 0 \cdot 24^{\mathrm{a}}$ \\
\hline
\end{tabular}

Hamsters were given $3 \mathrm{~cm}$ Silastic implants filled with testosterone (T), oestradiol (E, 10\% in cholesterol) or dihydrotestosterone (DHT) for 33 days. $\mathrm{LD}$ and SD controls received $3 \mathrm{~cm}$ cholesterol-filled Silastic implants. Letters denote significant differences between the treatment groups at $P<0.05$ or less (see text for specifics). Detection limits of assays are FSH $1.2 \mathrm{ng} / \mathrm{ml}$ and testosterone $0 \cdot 4 \mathrm{ng} / \mathrm{ml}$ respectively.

steroids did not affect serum $\mathrm{T}$ significantly compared with SD hamsters.

\section{Testicular steroids}

Testicular T, DHT, $3 \alpha$-Adiol and $3 \beta$-Adiol concentrations (ng/testis) in SD hamsters were reduced $(P<0 \cdot 01)$ compared with LD hamsters being 2, 5.2, 5 and $6 \%$ of LD values respectively (Table 2 ). When androgen concentrations were expressed on $\mathrm{ng} / \mathrm{g}$ testis basis, testicular $\mathrm{T}$ in SD hamsters was also reduced $(P<0 \cdot 001)$ to $35 \%$ of LD controls; however, there were no differences in the other androgens (Table 2). No significant differences were observed in testicular steroid concentrations in response to T, E and DHT treatments, but these results were partly confounded by wide animal variation. It is noteworthy that there was a $1 \cdot 7$-fold increase in testicular $\mathrm{T}$ concentrations following DHT and E treatments but not with $\mathrm{T}$ treatment, while testicular DHT concentrations increased twofold after DHT treatment (Table 2).

\section{Cell populations}

Sertoli cells A reduction in Sertoli cell number to $48 \%$ was observed in SD control hamsters $(P<0 \cdot 001$, Fig. 2) compared with LD controls following 11 weeks of photoinhibition. In response to $\mathrm{T}$ and $\mathrm{E}$ administration, Sertoli cell number was partially increased from SD control to 69\% (not significant) and $87 \%(P<0 \cdot 001)$ of LD control values respectively. DHT administration increased Sertoli cell number back to LD control values $(P<0 \cdot 001)$.

Early germ cells Compared with LD controls, a reduction in type A spermatogonial, type B spermatogonial/preleptotene spermatocyte and leptotene/zygotene spermatocyte number to 29,20 and 7\% respectively in SD control hamsters was observed (all $P<0 \cdot 001$, Fig. 2). In response to $\mathrm{T}$ and $\mathrm{E}$ administration, type A spermatogonial number tended to be increased (NS) above that of SD controls being 42 and 51\% of LD control values. DHT partially restored type A spermatogonial number $(P<0 \cdot 002)$ being $75 \%$ of LD control values (Fig. 1). T treatment did not alter type B spermatogonial/preleptotene spermatocyte and leptotene/zygotene spermatocyte number compared with $\mathrm{SD}$ control values (Fig. 2). In response to $\mathrm{E}$ and DHT administration, type B spermatogonial/preleptotene spermatocyte number were partially restored to 44 and $69 \%$ of LD control values $(P<0 \cdot 01)$ respectively (Fig. 2$)$. Oestradiol and DHT administration tended to increase leptotene/zygotene spermatocytes number above that of SD control values, although this did not achieve significance, being 15 and 40\% of LD control values respectively.

Later germ cells Less than $1 \%$ of the pachytene spermatocytes remained in SD controls compared with LD control $(P<0 \cdot 001$, Table 3$)$, while round and elongated spermatids were not detected in SD control hamsters except in the case of one animal. In response to DHT treatment, pachytene spermatocyte number increased to $21 \%$ of LD

Table 2 Testicular steroid concentrations (ng/testis and ng/g testis) in the photostimulated (long day, LD) adult Djungarian hamsters that were exposed to short photoperiods (short day, SD) for 11 weeks. Data are means \pm s.D., $n=6-8$ hamsters/group

Testicular T (ng/testis)

Testicular DHT (ng/testis)

\section{Treatment}

Long day control

Short day control

$+\mathrm{T}$

$+\mathrm{E}$

+ DHT

Long day control

Short day control

$+\mathrm{T}$

$+\mathrm{E}$

$+\mathrm{DHT}$

$$
\begin{gathered}
49 \cdot 4 \pm 25 \cdot 5^{\mathrm{a}} \\
0 \cdot 8 \pm 0 \cdot 1^{\mathrm{b}} \\
0 \cdot 8 \pm 0 \cdot 1^{\mathrm{b}} \\
1 \cdot 3 \pm 0 \cdot 9^{\mathrm{b}} \\
1 \cdot 4 \pm 0 \cdot 8^{\mathrm{b}} \\
103 \cdot 5 \pm 49 \cdot 9^{\mathrm{a}} \\
36 \cdot 8 \pm 10 \cdot 8^{\mathrm{b}} \\
31 \cdot 0 \pm 4 \cdot 4^{\mathrm{b}} \\
41 \cdot 2 \pm 18 \cdot 2^{\mathrm{b}} \\
22 \cdot 3 \pm 12 \cdot 0^{\mathrm{b}}
\end{gathered}
$$

$$
\begin{gathered}
17 \cdot 0 \pm 7 \cdot 0^{\mathrm{a}} \\
0 \cdot 9 \pm 0 \cdot 1^{\mathrm{b}} \\
1 \cdot 1 \pm 0 \cdot 7^{\mathrm{ab}} \\
1 \cdot 2 \pm 0 \cdot 4^{\mathrm{b}} \\
1 \cdot 8 \pm 0 \cdot 7^{\mathrm{b}} \\
36 \cdot 4 \pm 14 \cdot 3^{\mathrm{a}} \\
41 \cdot 0 \pm 8 \cdot 3^{\mathrm{a}} \\
42 \cdot 6 \pm 23 \cdot 4^{\mathrm{a}} \\
38 \cdot 8 \pm 10 \cdot 6^{\mathrm{a}} \\
28 \cdot 1 \pm 11 \cdot 6^{\mathrm{a}}
\end{gathered}
$$

Testicular $3 \boldsymbol{\alpha}$-Adiol (ng/testis)

Testicular 3 $\beta$-Adiol (ng/testis)

$$
\begin{gathered}
30 \cdot 4 \pm 13 \cdot 0^{\mathrm{a}} \\
1 \cdot 5 \pm 0 \cdot 7^{\mathrm{b}} \\
2 \cdot 3 \pm 1 \cdot 4^{\mathrm{b}} \\
2 \cdot 5 \pm 0 \cdot 8^{\mathrm{b}} \\
4 \cdot 5 \pm 3 \cdot 8^{\mathrm{b}} \\
63 \cdot 8 \pm 24 \cdot 5^{\mathrm{a}} \\
67 \cdot 2 \pm 37 \cdot 5^{\mathrm{a}} \\
87 \cdot 9 \pm 47 \cdot 5^{\mathrm{a}} \\
88 \cdot 8 \pm 42 \cdot 6^{\mathrm{a}} \\
74 \cdot 3 \pm 61 \cdot 3^{\mathrm{a}}
\end{gathered}
$$

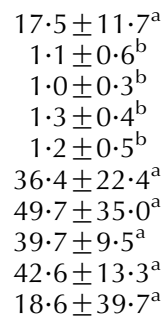

Hamsters were given $3 \mathrm{~cm}$ Silastic implants filled with testosterone (T), oestradiol (E, $10 \%$ in cholesterol) or dihydrotestosterone (DHT) for 33 days. LD and SD controls received $3 \mathrm{~cm}$ cholesterol-filled Silastic implants. Letters denote significant differences between the treatment groups at $P<0 \cdot 05$ or less. The assays sensitivity values are $0 \cdot 15 \mathrm{ng} / \mathrm{g}$ testis for T, $0 \cdot 30 \mathrm{ng} / \mathrm{g}$ testis for DHT, $0 \cdot 31 \mathrm{ng} / \mathrm{g}$ testis for $3 \alpha$-Adiol and $0 \cdot 61 \mathrm{ng} / \mathrm{g}$ testis for $3 \beta$-Adiol. Concentrations that were more than two standard deviations away from the mean were removed from the data set. 


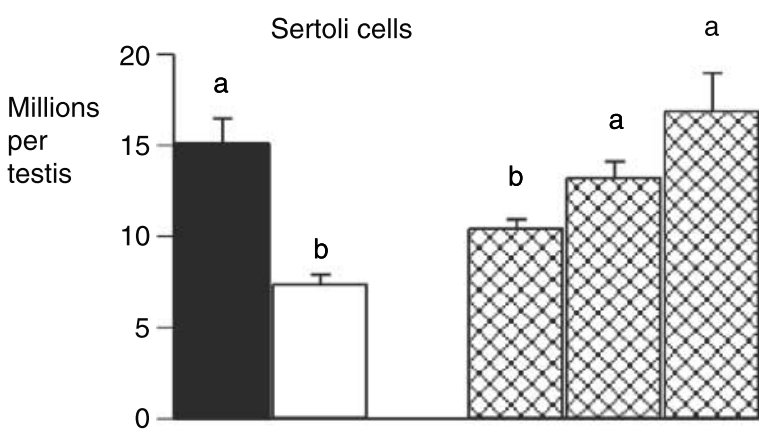

Type A/intermediate spermatogonia
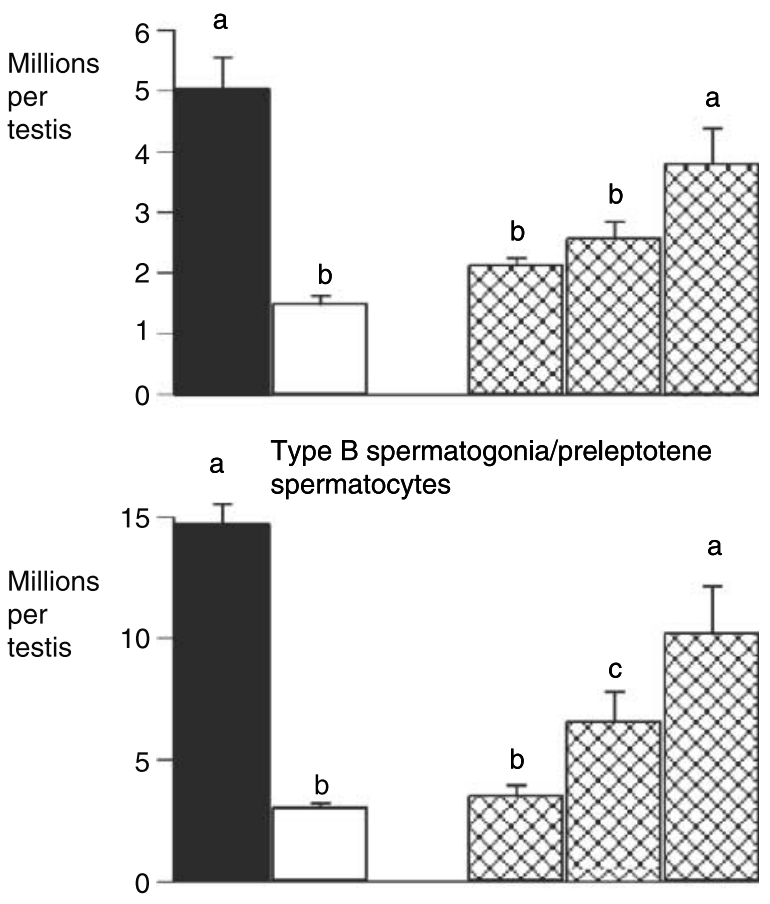

Leptotene/zygotene spermatocytes

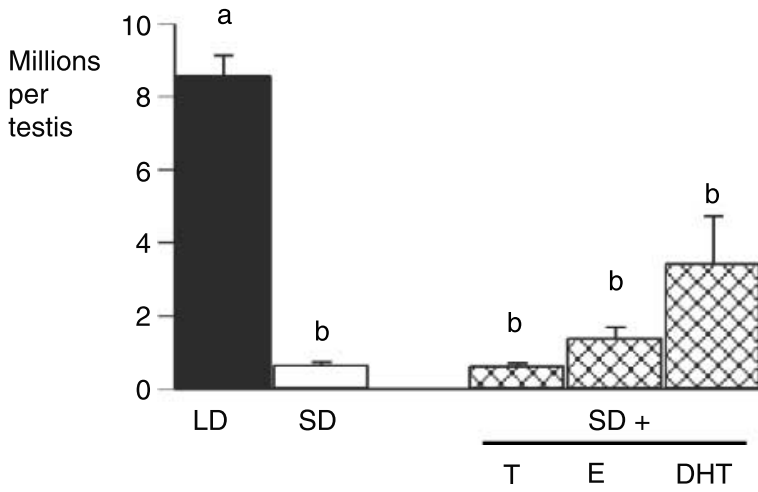

control respectively, compared with SD controls (Table 3). Oestradiol treatment tended to increase pachytene spermatocytes to $6 \%$ of LD control levels (NS), while T treatment had no effect (Table 3 ).

\section{Discussion}

In this study, we sought to establish the long-term (33 days) effect of T and its metabolites DHT and E on the re-initiation of Sertoli and germ cell numbers in the adult photoinhibited Djungarian hamster, as assessed by the optical disector (sic) stereological method. Serum and testicular hormone levels were monitored in all groups. Consistent with previous work (Meachem et al. 2005), this study demonstrates that the $95 \%$ decrease in testis weight observed after 11 weeks of photoinhibition, as a result of gonadotrophin suppression, is attributable to significant decreases in both the Sertoli and germ cell populations, with spermatogenesis being arrested at the level of the primary spermatocytes. This study suggests that steroids can regulate the re-initiation of early spermatogenic cells via a mechanism which includes FSH, but are not capable of supporting full spermatogenesis. More specifically, androgen in the form of DHT treatment increased Sertoli cell and spermatogonial numbers back to LD control levels, with a partial increase in spermatocyte numbers. Similarly, E restored Sertoli cell numbers and partially restored late spermatogonia and early spermatocyte populations. However, none of the steroids altered round spermatid or elongated spermatid numbers, which remained at SD levels. It is noteworthy that both DHT and E also produced an approximately twofold elevation in serum FSH. This study also provides new data regarding steroid concentrations (T, DHT, $3 \alpha$-Adiol and $3 \beta-$ Adiol) in the Djungarian hamster testis as a result of photoinhibition.

The mechanism by which steroids exert their effects on Sertoli and early germ cell numbers in this model remains unclear, although two models are proposed. First, steroids could support Sertoli and early germ cells directly via an FSHindependent pathway, or secondly, steroids could operate via a mechanism which includes the stimulation of FSH production from the pituitary. In support of the former, both androgen (McLachlan et al. 2002) and oestrogen receptors ( $\beta$ ) are present on rat Sertoli cells, while oestrogen receptor $\beta$ is also present on

Figure 2 The number of Sertoli cell, type A/intermediate spermatogonia, type B spermatogonia/preleptotene spermatocytes and leptotene/zygotene spermatocytes (millions per testis) in the photostimulated (long day, LD) adult Djungarian hamsters that were exposed to short photoperiods (short day, SD) for 11 weeks. Hamsters were then given $3 \mathrm{~cm}$ Silastic implants filled with testosterone $(\mathrm{T})$, oestradiol $(\mathrm{E}, 10 \%$ in cholesterol) or dihydrotestosterone (DHT) for 33 days. Long (LD) and short day (SD) controls received $3 \mathrm{~cm}$ cholesterol-filled Silastic implants. Data are means \pm S.E.M., $n=8$ hamsters/group. Letters denote significant differences between the treatment groups at $P<0 \cdot 05$ or less (see text for specifics). 
Table 3 The number of pachytene spermatocytes and round and elongated spermatids per testis in photo-stimulated (long day, LD) adult Djungarian hamsters that were exposed to short photoperiods (short day, SD) for 11 weeks and then given $3 \mathrm{~cm}$ Silastic implants filled with testosterone $(\mathrm{T})$, oestradiol $(\mathrm{E}, 10 \%$ in cholesterol) or dihydrotestosterone (DHT) for 33 days. Data are means \pm s.E.M., $n=8$ hamsters/group

Pachytene spermatocytes (millions/testis)

\section{Treatment}

Long day control $\quad 55 \cdot 4 \pm 3 \cdot 2^{\mathrm{a}}$

Short day control $0.53 \pm 0 \cdot 17^{\mathrm{b}}$

$+\mathrm{T} \quad 0.95 \pm 0 \cdot 32^{\mathrm{b}}$

$+\mathrm{E} \quad 3 \cdot 29 \pm 1 \cdot 02^{\mathrm{b}}$

+ DHT $\quad 10 \cdot 1 \pm 2 \cdot 03^{\mathrm{c}}$
Round spermatids (millions/testis)

Elongated spermatids (millions/testis)

$142 \pm 12 \cdot 2^{a}$
$0 \cdot 00 \pm 0 \cdot 00^{b}$
$0 \cdot 12 \pm 0 \cdot 14^{b}$
$0 \cdot 08 \pm 0 \cdot 05^{b}$
$1 \cdot 91 \pm 0 \cdot 75^{b}$

$123 \pm 8 \cdot 7^{\mathrm{a}}$

$0 \cdot 01 \pm 0 \cdot 01^{b}$

$0 \cdot 03 \pm 0 \cdot 02^{b}$

$0 \cdot 02 \pm 0 \cdot 02^{\mathrm{b}}$

$0.04 \pm 0.03^{\mathrm{b}}$

LD and SD controls received $3 \mathrm{~cm}$ cholesterol-filled Silastic implants. Letters denote significant differences between the treatment groups or $P<0 \cdot 05$ or less (see text for specifics).

rat spermatogonia (O'Donnell et al. 2001). Whether these localisations are true for the hamster remains unknown although oestrogen receptor $\alpha$ and $\beta$ message has been found in testis extracts (Karri et al. 2004) and androgen receptor protein is expressed in the somatic cells of the testis (S J Meachem, unpublished data). Oestrogen has been claimed elsewhere to have FSH-independent stimulatory effects on hamster spermatogenesis in both immature (Pak et al. 2001) and adult SD animals (Pak et al. 2002), although the extent of this independence is a moot point given that FSH potencies could not be accurately determined. In addition, these authors show that $\mathrm{E}$ acts via a different pathway compared with that of $\mathrm{T}$ and DHT to inhibit puberty in the male Siberian hamster (Pak et al. 2001). Testosterone in the current model was ineffective in supporting Sertoli and germ cell development, possibly as a result of the dose of $\mathrm{T}$ administered. It is speculated that a higher dose of Twould emulate the DHT response, which has been shown elsewhere to be up to tenfold more potent than $\mathrm{T}$ (Deslypere et al. 1992), although this calculation is complicated by an approximately $30 \%$ slower release rate of DHT than T from Silastic implants (Ahmad et al. 1973). Nonetheless, the changes in gross organ weights of the androgen-dependent organs (prostate, seminal vesicle) demonstrate that both administered androgens were biologically active. Finally, in the normal Djungarian hamster, there is no data thus far to suggest a role for $\mathrm{T}$ in promoting the re-initiation of spermatogenesis (Lerchl et al. 1993, Meachem et al. 2005), and $\mathrm{T}$ has only been reported to be important for mounting behaviour (Lerchl et al. 1993).

The second model is that the observed steroidal effects were a consequence of the stimulation of FSH production from the pituitary. This seems likely since a mild increase in serum FSH was observed in DHT- and E-treated hamsters, consistent with effects seen on the re-initiation of early germ cells and the Sertoli cell population. A similar mechanism of E-stimulated FSH production in the $h p g$ mouse has also been shown to induce spermatogenesis (Ebling et al. 2000). It is known that FSH plays a major role in regulating Djungarian hamster spermatogenesis (Lerchl et al. 1993), in particular in the early phase of the re-initiation process of Sertoli and germ cells (spermatogonia and spermatocytes; Meachem at al. 2005). However, whether sub-physiological levels of FSH are capable of having significant effects on the hamster spermatogenic process has yet to be determined. Evidence in gonadotrophindeplete adult rats, a species considered to be less dependent on FSH than the hamster, has shown that even a low FSH level has substantial stimulatory effects on spermatogonial and spermatocyte number (Meachem et al. 1998).

In line with our previous work (Meachem et al. 2005), this study has shown that the adult Sertoli cell population can be hormonally regulated as evidenced by a $50 \%$ reduction in the Sertoli cell population after photoinhibition and a full or partial restoration to LD values with DHT and E respectively via a mechanism which includes $\mathrm{FSH}$, within 33 days of exogenous treatment. Testosterone had little to no effect on Sertoli cell number, presumably due to the lack of rise in FSH as a result of dose-related effects (discussed above). We have previously shown that the adult Sertoli cell population is hormonally dependent in the Djungarian hamster (Meachem et al. 2005) and that these Sertoli cells can re-enter the cell cycle and proliferate in response to FSH (Tarulli et al. 2006).

In order to identify sites of hormone action on the spermatogenic process, the following assumptions require consideration. The stereological approach depends on the morphological classification of germ cells, which in turn is partly based on cell association patterns (i.e. staging) of which there are 12 stages in the Djungarian hamster (Van Haaster \& de Rooij 1993). Staging is unreliable in the SD hamster due to the severe regression and the lack of specific markers to allow morphological discrimination of type A spermatogonial subtypes from intermediate and type B spermatogonia and preleptotene spermatocytes. Hence, germ cells were classified into broader categories based on their morphological characteristics without any reference to staging. The limitation of pooling germ cells into broader categories is that effects on particular germ cell subpopulations can be masked. It has been assumed that a steady state of germ cell development under the influence of each treatment has been established over the 33-day period of this study, and the rate of germ cell development is not altered by gonadotrophin withdrawal in the SD adult hamster, as has previously been demonstrated in the gonadotrophin-withdrawn adult rat model (Clermont \& Harvey 1965). To assess Sertoli and germ cell numbers, this study has used a modern stereological 
approach, which is an unbiased and assumption-free method applicable to the assessment of non-spherical particles such as the nuclei of Sertoli cells, spermatogonia and elongated spermatids (Wreford 1995). Tissue distortion measurements for Bouin's-fixed methacrylate-processed tissue have been made in our laboratory on a number of occasions (McLachlan et al. 1995, Meachem et al. 1996) with negligible distortion observed and thus cell estimates were not adjusted.

Spermatogonial number increased proportionately with the rise in the Sertoli cell population, consistent with the Sertoli cell providing the stem cell niche. Conversion ratios to understand the efficiency of germ cells progressing to the next step in spermatogenesis were examined (data not shown). No changes were observed between any germ cell type in any of the hormonally manipulated groups, except for DHT, which supported primary spermatocytes progressing to pachytene spermatocytes at similar levels to that observed in LD levels (70\% efficiency) compared with $<20 \%$ in SD animals regardless of $\mathrm{E}$ and $\mathrm{T}$ treatments. Spermatogenesis did not proceed past that of pachytene spermatocytes after steroid treatment (with the majority of pachytene spermatocytes being in stages I-VIII, not IX-XIII) even after 33 days, which is sufficient time for a spermatogonium to become an elongated spermatid. The most likely explanation as to why full spermatogenesis was not achieved in this model is because FSH levels may be suboptimal to support spermatid maturation, as discussed above. However, it cannot be ruled out that testicular androgen levels may not have been adequate in this model. Although increases in DHT and T are reported here, these did not achieve significance, due to wide animal variation. All steroids administered were clearly biologically active at the serum level due to their effects on secondary sexual organs as well as the described testicular changes. In rats, only small changes in testicular $T$ are required to have significant effects on spermatogenesis, most notably spermiogenesis (Meachem et al. 1997, 1998).

Our analysis of the intratesticular concentrations of $\mathrm{T}$, DHT and both $3 \alpha$-Adiol and 3 $\beta$-Adiol in the Djungarian hamster in vivo has revealed a number of interesting points. First, the concentrations of DHT, $3 \alpha$-Adiol and $3 \beta$-Adiol per gram testis were not altered between LD and SD animals, although $\mathrm{T}$ was significantly decreased. Hence, it does not appear that intratesticular DHT, $3 \alpha$-Adiol and $3 \beta$-Adiol play any local role in the testicular changes that occur during regression. In contrast, ratios of 6- to 35-fold between LD and $\mathrm{SD}$ values for DHT and $3 \alpha$-Adiol production by testicular homogenates have been reported for the golden hamster (Frungieri et al. 1999). It is not clear why this apparent species difference exists, but is most likely due to differences between the in vivo and in vitro measurement systems used. In our Djungarian hamster data, the total testicular concentrations (i.e. ng steroid/testis) of all of the androgens fell precipitously (16- to 60-fold) in line with the changes in testis weights between LD and SD animals, as observed elsewhere (Schlatt et al. 1995). It is also noteworthy that we did not observe an elevated level of $3 \alpha$-Adiol in SD animal testis, which in the golden hamster testis has been shown to be approximately eightfold greater per gram testis than testosterone (Frungieri et al. 1999). Again, the significance of this difference remains unknown.

In conclusion, this study demonstrates that $\mathrm{T}$ and its metabolites differentially regulate the initial phase of the re-initiation of Djungarian hamster spermatogenesis via a mechanism that includes FSH. DHT and E increased Sertoli cell, spermatogonial and spermatocyte populations, but $\mathrm{T}$ was ineffective. Steroid treatment provided little to no support for spermatid development.

\section{Acknowledgements}

Thank you to Anne Leuer, Viktoria vön Schönfeldt, Joachim Wistuba, Kaye Xu, Reinhildt Sandhowe and Fiona McLean for their excellent technical assistance. Supported by the Wellcome Trust Fellow Scheme, UK \# 058479 (S J M), the National Health and Medical Research Council of Australia \#241000 (S J M, P G S) and the Deutsche Forschungspermatogonialemeinschaft (S S, Schl 394/3). The authors declare that there is no conflict of interest that would prejudice the impartiality of this scientific work.

\section{References}

Ahmad N, Haltmeyer GC \& Eik-Nes KB 1973 Maintenance of spermatogenesis in rats with intratesticular implants containing testosterone or dihydrotestosterone (DHT). Biology of Reproduction 8 411-419.

Bartlett JM, Weinbauer GF \& Nieschlag E 1989 Differential effects of FSH and testosterone on the maintenance of spermatogenesis in the adult hypophysectomized rat. Journal of Endocrinology 121 49-58.

Bergmann M 1987 Photoperiod and testicular function in Phodopus sungorus. Advances in Anatomy, Embryology, and Cell Biology 105 1-76.

Chandolia RK, Weinbauer GF, Fingscheidt U, Bartlett JMS \& Nieschlag E 1991 Effects of flutamide on testicular involution induced by an antagonist of gonadotrophin-releasing hormone and on stimulation of spermatogenesis by follicle-stimulating hormone in rats. Journal of Reproduction and Fertility 93 313-323.

Chen H, Chandrashekar V \& Zirkin BR 1994 Can spermatogenesis be maintained quantitatively in intact adult rats with exogenously administered dihydrotestosterone? Journal of Andrology 15 132-138.

Clermont Y \& Harvey SC 1965 Duration of the cycle of the seminiferous epithelium of normal, hypophysectomized and hypophysectomizedhormone treated albino rats. Endocrinology 76 80-89.

Deslypere JP, Young M, Wilson JD \& McPhaul MJ 1992 Testosterone and $5 \alpha$-dihydrotestosterone interact differently with the androgen receptor to enhance transcription of the MMTAV-CAT reporter gene. Molecular and Cellular Endocrinology 88 15-22.

Ebling FJ, Brooks AN, Cronin AS, Ford H \& Kerr JB 2000 Estrogenic induction of spermatogenesis in the hypogonadal mouse. Endocrinology 141 2861-2869.

Frungieri MB, Gonzalez-Calvar SI, Bartke A \& Calandra RS 1999 Influence of age and photoperiod on steroidogenic function of the testis in the golden hamster. International Journal of Andrology 4 243-252.

Grino PB, Griffin JE \& Wilson JD 1990 Testosterone at high concentrations interacts with the human androgen receptor similarly to dihydrotestosterone. Endocrinology 126 1165-1172. 
Hess RA, Bunick D, Lee KH, Bahr J, Taylor JA, Korach KS \& Lubahn DB 1997 A role for oestrogens in the male reproductive system. Nature 390 509-512.

Karri S, Johnson H, Hendry WJ, Williams SC \& Khan SA 2004 Neonatal exposure to diethylstilbestrol leads to impaired action of androgens in adult male hamsters. Reproductive Toxicology 19 53-63.

Lerchl A 1995 Breeding of Djungarian hamsters (Phodopus sungorus): influence of parity and litter size on weaning success and offspring sex ratio. Laboratory Animals 29 172-176.

Lerchl A, Sotiriadou S, Behre HM, Pierce J, Weinbauer GF \& Nieschlag E 1993 Restoration of spermatogenesis by follicle-stimulating hormone despite low intratesticular testosterone in photoinhibited hypogonadotropic Djungarian hamsters (Phodopus sungorus). Biology of Reproduction 49 1108-1116.

Matthiesson KL, Stanton PG, O'Donnell L, Meachem SJ, Amory JK, Berger R, Bremner WJ \& McLachlan RI 2005 Effects of testosterone and levonorgestrel combined with a $5 \alpha$-reductase inhibitor or gonadotropinreleasing hormone antagonist on spermatogenesis and intratesticular steroid levels in normal men. Journal of Clinical Endocrinology and Metabolism 90 5647-5655.

McLachlan RI, Wreford NG, Meachem SJ, de Kretser DM \& Robertson DM 1994 Effects of testosterone on spermatogenic cell populations in the adult rat. Biology of Reproduction $\mathbf{5 1}$ 945-955.

McLachlan RI, Wreford NG, de Kretser DM \& Robertson DM 1995 The effects of recombinant follicle-stimulating hormone on the restoration of spermatogenesis in the gonadotropin-releasing hormone-immunized adult rat. Endocrinology 136 4035-4043.

McLachlan RI, O'Donnell L, Meachem SJ, Stanton PG, deKretser DM, Pratis K \& Robertson DM 2002 Identification of specific sites of hormonal regulation in spermatogenesis in rats, monkeys and man. Recent Progress in Hormone Research 57 149-179.

Meachem SJ, McLachlan RI, de Kretser DM, Roberston DM \& Wreford NG 1996 Neonatal exposure of rats to recombinant follicle stimulating hormone increases adult Sertoli and spermatogenic cell numbers. Biology of Reproduction 54 36-44.

Meachem SJ, Wreford NG, Robertson DM \& McLachlan RI 1997 Androgen action on the restoration of spermatogenesis in adult rats: effects of human chorionic gonadotrophin, testosterone and flutamide administration on germ cell number. International Journal of Andrology 20 70-79.

Meachem SJ, Wreford NG, Stanton PG, Robertson DM \& McLachlan RI 1998 Follicle-stimulating hormone is required for the initial phase of spermatogenic restoration in adult rats following gonadotrophin suppression. Journal of Andrology 19 725-735.

Meachem SJ, Stanton PG \& Schlatt S 2005 Follicle stimulating hormone (FSH) regulates both Sertoli cell and spermatogonial populations in the adult photo-inihibited Djungarian hamster testis. Biology of Reproduction 72 1187-1193.

Milette JJ, Schwartz NB \& Turek FW 1988 The importance of folliclestimulating hormone in the initiation of testicular growth in photostimulated Djungarian hamsters. Endocrinology 122 1060-1066.

Niklowitz P, Khan S, Bergmann M, Hoffmann K \& Nieschlag E 1989 Differential effects of follicle-stimulating hormone and luteinizing hormone on Leydig cell function and restoration of spermatogenesis in hypophysectomized and photoinhibited Djungarian hamsters (Phodopus sungorus). Biology of Reproduction 41 871-880.

Niklowitz P, Lerchl A \& Nieschlag E 1997 In vitro fertilizing capacity of sperm from FSH-treated photoinhibited Djungarian hamsters (Phodopus sungorus). Journal of Endocrinology 154 475-481.

Nonclercq D, Reverse D, Toubeau G, Beckers JF, Sulon J, Laurent G, Zanen J \& Heuson-Stiennon JA 1996 In situ demonstration of germinal cell apoptosis during diethylstilbestrol-induced testis regression in adult male Syrian hamsters. Biology of Reproduction 55 1368-1376.
O’Donnell L, Stanton PG, Wreford NG, Robertson DM \& McLachlan RI 1996 Inhibition of $5 \alpha$-reductase activity impairs the testosteronedependent restoration of spermiogenesis in adult rats. Endocrinology 137 2703-2710.

O'Donnell L, Pratis K, Stanton PG, Robertson DM \& McLachlan RI 1999 Testosterone-dependent restoration of spermatogenesis in adult rats is impaired by a 5alpha-reductase inhibitor. Journal of Andrology 20 109-117.

O'Donnell L, Robertson KM, Jones ME \& Simpson ER 2001 Estrogen and spermatogenesis. Endocrine Reviews 22 289-318.

Oliveira CA, Carnes K, Franca LR \& Hess RA 2001 Infertility and testicular atrophy in the antiestrogen-treated adult male rat. Biology of Reproduction $\mathbf{6 5}$ 913-920.

Oliveira CA, Zhou Q, Carnes K, Nie R, Kuehl DE, Jackson GL, Franca LR, Nakai M \& Hess RA 2002 ER function in the adult male rat: short- and long-term effects of the antiestrogen ICI 182,780 on the testis and efferent ductules, without changes in testosterone. Endocrinology 143 2399-2409.

Pak TR, Lynch GR \& Tsai PS 2001 Testosterone and estrogen act via different pathways to inhibit puberty in the male Siberian hamster (Phodopus sungorus). Endocrinology 142 3309-3316.

Pak TR, Lynch GR \& Tsai PS 2002 Estrogen accelerates gonadal recrudescence in photo-regressed male siberian hamsters. Endocrinology 143 4131-4134.

Robaire B, Ewing LL, Irby DC \& Desjardings C 1979 Interactions of testosterone and estradiol-17 $\beta$ on the reproductive tract of the male rat. Biology of Reproduction 21 455-463.

Robertson KM, O'Donnell L, Jones ME, Meachem SJ, Boon WC, Fisher CR, Graves KH, McLachlan RI \& Simpson ER 1999 Impairment of spermatogenesis in mice lacking a functional aromatase (cyp 19) gene. PNAS 96 7986-7991.

Russell LD, Ettlin RA, Sinha Hikim AP \& Clegg ED 1990 Histological and Histopathological Evaluation of the Testis I, pp. 62-118. Clearwater, Florida: Cache River Press.

Schlatt S, De Geyter M, Kliesch S, Nieschlag E, Bergmann M, Nieschlag E \& Bergmann M 1995 Spontaneous recrudescence of spermatogenesis in the photoinhibited male Djungarian hamster, Phodopus sungorus. Biology of Reproduction 53 1169-1177.

Tarulli GA, Stanton PG, Lerchl A \& Meachem SJ 2006 Adult Sertoli cells are not terminally differentiated in the Djungarian hamster: effect of FSH on proliferation and junction protein organization. Biology of Reproduction $\mathbf{7 4}$ 798-806.

van Haaster LH \& De Rooij DG 1993 Cycle of the seminiferous epithelium in the Djungarian hamster (Phodopus sungorus). Biology of Reproduction $\mathbf{4 8}$ 515-521.

Wilson J 1975 Metabolism of Testicular Androgens. In: Handbook of Physiology, Section 7, Vol V, pp 491-508. Eds RO Greep \& EB Astwood, Waverly Press, Inc., Maryland.

Wreford NG 1995 Theory and practice of stereological techniques applied to the estimation of cell number and nuclear volume in the testis. Microscopy Research and Technique 32 423-436.

Zhou Z, Lane MV, Kemppainen JA, French FS \& Wilson EM 1995 Specificity of ligand-dependent androgen receptor stabilization: receptor domain interactions influence ligand dissociation and receptor stability. Molecular Endocrinology 9 208-218.

\section{Received in final form 4 December 2006 Accepted 6 December 2006 Made available online as an Accepted Preprint 28 December 2006}

